Portland State University

PDXScholar

Anthropology Faculty Publications and

Presentations

Anthropology

2008

\title{
Large Domestic Pits on the Northwest Coast of North America
}

\author{
Kenneth M. Ames \\ Portland State University, amesk@pdx.edu \\ Cameron M. Smith \\ Portland State University \\ Alexander Bourdeau \\ United States Fish and Wildlife Service
}

Follow this and additional works at: https://pdxscholar.library.pdx.edu/anth_fac

Part of the Anthropology Commons

Let us know how access to this document benefits you.

\section{Citation Details}

Ames, K. (2008). Large domestic pits on the Northwest Coast of North America. Journal Of Field Archaeology, 33(1), 3-18.

This Article is brought to you for free and open access. It has been accepted for inclusion in Anthropology Faculty Publications and Presentations by an authorized administrator of PDXScholar. Please contact us if we can make this document more accessible: pdxscholar@pdx.edu. 


\title{
Large Domestic Pits on the Northwest Coast of North America
}

\author{
Kenneth M. Ames \\ Cameron McP. Smith \\ Portland State University \\ Portland, Oregon
}

\begin{abstract}
Alexander Bourdeau
United States Fish and Wildlife Service

Tualatin, Oregon
\end{abstract}

Excavations of prehistoric and Contact-period houses on the southern Northwest Coast of North America have exposed very large interior pit complexes. The complexes are either long trenches or rows of pits beneath the house floors. They are associated with substantial permanently occupied houses dated to between 300 CAL B.C. and A.D. 1830. The pits add significantly to the storage potentials of these houses and suggest surplus production.

\section{Introduction}

Over the past 30 years, excavations within prehistoric and Contact-period houses along the Lower Columbia River (FIG. I) of the Nw United States have exposed sometimes enormous interior pit complexes. These complexes in certain cases warrant the name "cellars." Currently dated between ca. 300 CAL B.C. and A.D. 1830 (see below) the complexes are composed of multiple, intersecting pits within trenches aligned along the dwellings' long axes. The pits significantly increase the storage capacity of the houses above them. As far as we can determine, the scope of these complexes is very unusual for hunter-gatherers.

There is continuing debate on the role of storage in the evolution of social and economic complexity, particularly (but not exclusively) among hunter-gatherers (Arnold 1996; Bursey 2001; DeBoer 1988; Hayden 1995; Ingold 1983, 1987; Testart 1982; Wesson 1999). Scholars once assumed storage was fundamental to the development of social inequality and complexity (e.g., Ames 1981; Testart 1982; Price and Brown 1985). More recent thinking challenges this apparently simple causal linkage (Matson 1985; Hayden 1995; Arnold 1996). Nevertheless, storage can be crucial to complex hunter-gatherer economies (Binford 2001; Kelly 1995) and likely played a variety of important roles in the evolution of political systems regardless of subsistence economy (DeBoer 1988; Strasser 1997; Wesson 1999). Storage and storage facilities can be central to the organization of household economies, the long-term via- bility of households, and the integration of households into larger scale socio-economic structures (Gallant 1991; Christakis 1999).

Theoretical discussions of storage generally focus on the stores themselves as surplus and as objects of labor and control. Archaeologists, however, generally find storage facilities (Bursey 2001) rather than the perishable stores they contained. While facilities may be evidence for food storage, they are also objects of labor and can be controlled by members of families, households, or communities. They can also play other important roles in household dynamics (Fraser D. Neiman, personal communication 2004; Samford 1996; Young 1995). In addition to the stores, construction and maintenance of extensive storage facilities are important parts of a political economy because of the labor invested in their construction and the possibilities for their control by various entities.

The significance of the Lower Columbia River features lies in their large size, consistent layouts, and interior locations. The kinds and capacities of storage facilities are common proxy measures for the amount of stores and surpluses produced annually by an economy. The locations of storage facilities are often used to infer who controlled stores and surpluses in a society. Storage facilities may be pits and cellars, but they can also be racks, platforms, caves, and buildings. They may be placed near residences or some distance away. Racks, platforms, and even structures, however, can have little or no archaeological visibility. Storage pits are recoverable archaeologically and can be used to de- 




Figure 1. The Lower Columbia River region with areas and sites mentioned. Base map drafted by Jon Franczyk.

velop minimum estimates of the potential to produce and store processed foods when present.

Another significant aspect of pit complexes rests in their association with hunter-gatherers. It has become clear over the past 30 years that prehistoric hunter-gatherers were much more socially and economically diverse than those of the historical times. Phrases such as "complex hunter-gatherers," "affluent foragers," and "low-level food producers" have been developed to describe this diversity. Bruce Smith (2001: 15) coined the last phrase to establish a third alternative to the dichotomy between hunter-gatherers (food procurers) and agriculturalists (food producers); "low-level food producers" may or may not use domesticates, but manipulate resources and ecosystems to increase and manage productivity. His emphasis is on what is exploited and how it is manipulated, not on how much is produced and processed. The capacity to produce surpluses and the potential size of those surpluses is of equal significance to a political system. The features discussed here show that significant surpluses are possible among low-level food producers. Here we describe the features in the Greater Lower Columbia Region (GLCR), including their geographic distribution and chronology. We compare their locations and capacities with other archaeologically-documented hunter-gatherer and agricultural storage facilities to demonstrate that these features are comparatively quite large.

\section{Background}

\section{The Region}

The GLCR (Hajda 1984; FIG. I) encompasses the Columbia River's final $275 \mathrm{~km}$ run to its confluence with the Pacific Ocean and the adjacent coastal regions of the states of Oregon and Washington. Of the five physiographic zones it flows through, the four western ones are relevant here. The most easterly is the Columbia River Gorge where the river cuts through the Cascade Mountain Range. The Wapato Valley (the Portland Basin) is west of the Gorge and contains the Columbia's run between the Sandy and Cowlitz Rivers, the Columbia's floodplain, adjacent low plateaus, and the cities of Portland, Oregon, and Vancouver, Washington. Upon leaving the Wapato Valley, the Columbia River turns north and then west where it enters its broad estuary. The last physiographic zone is the Pacific coastline at the river's mouth.

Several ethnolinguistic groups representing three distinct language families occupied the GLCR at contact. Speakers of Chinookan languages (Hajda 1984; Silverstein 1990) were the most numerous. Populations were large 


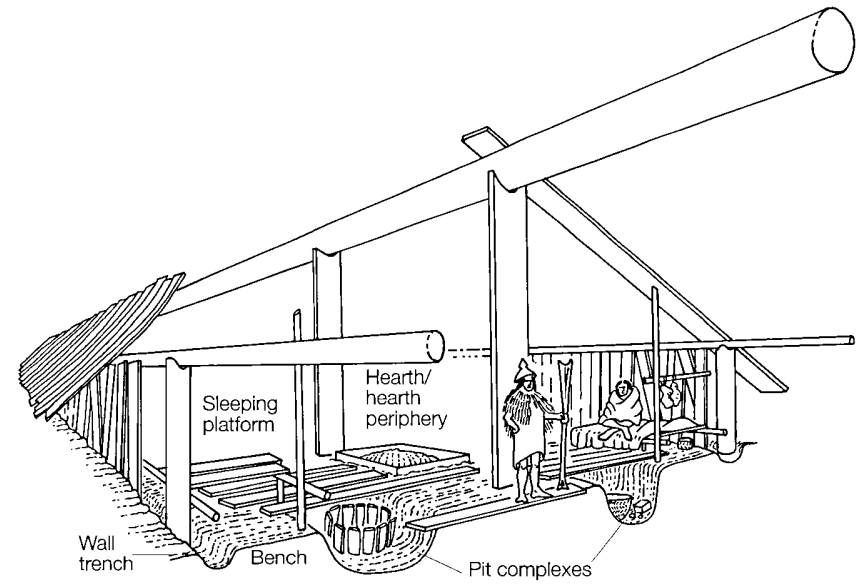

Figure 2. Architectural and archaeological features associated with a Columbia River plank house. The pit complexes are not to scale in the drawing and appear too small.

and comparatively dense, ranking 26th worldwide among 205 foraging societies (Kelly 1995: table 6-4). Robert Boyd conservatively estimates Precontact period populations at 34,000 people (Boyd 1990, 1999) concentrated on the major rivers and tributaries, particularly in the Wapato Valley (FIG. I). Chinookan social organization and economy shared much with other Northwest Coast societies (Hajda 1984; Silverstein 1990), with multi-family households comprising basic economic and social units. Society was divided into two broad classes, free and slave (Donald 1997; Hajda 2005). The storage-based subsistence economy produced large volumes of foods based on broad-spectrum harvesting of a wide array of fish, plants, and wetland and upland mammals (Saleeby 1983; Boyd and Hajda 1987). Trade and exchange, both within the GLCR and beyond, were important activities particularly among Chinookan speakers.

Plank houses, the physical manifestations of these households, were our focus (Ames 1995, 1996; Smith 2004; Sobel 2004; Ames et al. 1992; Sobel, Gahr, and Ames 2006). In the GLCR, plank houses were gableroofed, rectangular, and built of western red cedar (Thuja plicata) posts, beams, and planks (Vastokas 1966; Suttles 1990; Ames et al. 1992; FIG. 2). This brief description masks important spatial and seasonal variation (Hajda 1994). Here it is sufficient to distinguish between simple open houses (usually just termed "houses"), having undivided interiors, and houses in which the larger structure is composed of several permanently connected compartments (FIG. 3). We also distinguish between permanent houses and temporary houses (Ellis 2006; Ellis and Fagan 1993). The larger permanent houses had interior platforms (benches), 1-2 m wide, along the walls (FIG. 2) that served for sleeping, storage, and other functions. Smaller structures had one central hearth and larger ones had multiple hearths aligned in a row along the central axes. Floors could be earthen or planked (Ames et al. 1992; Sobel 2004). Elizabeth Sobel (2004) reviews the distribution of stores within these houses and finds that baskets and bags of food and other items were stored under and on the benches on racks, suspended from rafters, and placed in the cellar pits. The architectural elements (walls, posts, etc.) are represented archaeologically by a range of features (Ames et al. 1992). The permanent houses were occupied for centuries and are associated with extensive sheet trash (Wilson 1994) and deep middens. The temporary structures were occupied for much briefer periods and the associated sheet trash and midden deposits are often quite limited or absent.

\section{The Sites}

Pit complexes are well documented at six GLCR sites (FIG. I). Clahclellah (45SAll) is a village in the Columbia River Gorge of seven plank houses in two rows dating between ca. A.D. 1700, if not earlier, and A.D. 1855 (Sobel 2004; Minor, Toepel, and Beckham 1989). They were completely excavated in 1977-1979 in a data recovery project. The village is mentioned in early historical accounts, including by Lewis and Clark (Moulton 2002). The houses were comparatively small (ca. $76 \mathrm{sq}$ m; Ames 1996) with single central hearths and probably had open, undivided interiors.

Cathlapotle $(45 \mathrm{CLl})$ is the site of a large native town (Ames et al. 1999) in the Wapato Valley (FIG. I) excavated between 1991 and 1996 (Ames et al. 1999). It was first observed by Europeans in 1792 (Vancouver 1926), visited in 1806 by Lewis and Clark who left descriptions in their journals (Moulton 2002), and mentioned in other furtrade era accounts (Sobel 2004). The site contains visible depressions of six large semi-subterranean structures aligned in two rows (FIG. 3) paralleling and fronting a small tributary of the Columbia River. A seventh structure is deeply buried beneath House 2. Houses 1 and 4 were extensively sampled; Houses 2 and 6 were tested, and Houses 3 and $\mathbf{5}$ were augered only. House $\mathbf{l}$ is the largest structure, while House 4 is one of the two smallest (TABLE I). It is not clear whether House 4 was a compartmented structure or had an open interior, although the latter is more likely. House 1 has four interior subdivisions. Three have been sampled. Cathlapotle was established at its present location around A.D. 1450 (Ames et al. 1999) and was virtually abandoned after 1833 (Kaehler 2002; Sobel 2004; Ames et al. 1999). 
Table 1. House floor and pit sizes and estimated storage potentials (in liters).

\begin{tabular}{|c|c|c|c|c|}
\hline \multirow[b]{2}{*}{ Site } & \multicolumn{2}{|l|}{ Houses } & \multicolumn{2}{|l|}{ Pits } \\
\hline & $\#$ & $S q m$ & Liters & Liters/house sq $m$ \\
\hline \multirow{2}{*}{ Meier } & 1 & & & \\
\hline & 1 & 491.7 & 127,000 & 258.29 \\
\hline Cathlapotle & $\mathrm{Hl}$ & 410 & 92,000 & 224.39 \\
\hline & $\mathrm{Hlb}, \mathrm{c}, \mathrm{d}$ & 310 & 67,000 & $\begin{array}{l}224.39 \\
216.13\end{array}$ \\
\hline & $\mathrm{H} 4$ & 104 & 52,000 & 500.00 \\
\hline \multicolumn{5}{|l|}{ Clahclellah } \\
\hline & 1 & 106.7 & 1301 & 12.19 \\
\hline & $2 / 3$ & 110.16 & 3252 & 29.52 \\
\hline & $2 / 2$ & 85 & 3928 & 46.21 \\
\hline & $2 / 1$ & - & 2684 & - \\
\hline & $3 / 2$ & - & 3211 & - \\
\hline & $3 / 1$ & 70.4 & 1180 & 16.76 \\
\hline & $4 / 3$ & 70.4 & 2581 & 36.66 \\
\hline & $4 / 2$ & 76.5 & 4521 & 59.09 \\
\hline & $4 / 1$ & 88 & 1130 & 12.84 \\
\hline & $5 / 3$ & 84 & 3970 & 47.26 \\
\hline & $5 / 2$ & 55.9 & 1037 & 18.55 \\
\hline & $5 / 1$ & 73.6 & 5281 & 71.75 \\
\hline & $6 / 2$ & - & 1154 & - \\
\hline & $6 / 1$ & - & 2932 & - \\
\hline \multicolumn{5}{|l|}{ Keatley Creek } \\
\hline & HP 12 & 38.5 & 772 & 20.05 \\
\hline & HP 3 & 78.5 & 1747 & 22.25 \\
\hline & HP 7 & 113.1 & 7928 & 70.09 \\
\hline & HP 9 & 20.5 & 1022 & 49.85 \\
\hline \multicolumn{5}{|l|}{$\begin{array}{l}\text { Cretan Houses } \\
\text { A.D. } 1898-1940\end{array}$} \\
\hline & Group 1: 353 & - & $<2000$ & - \\
\hline & Group 2: 186 & - & $4000-8000$ & - \\
\hline & Group 3: 81 & - & $12,000-24,000$ & - \\
\hline $1700-1450 \mathrm{~B} . \mathrm{C}$ & Type 3 & - & $800-1200$ & - \\
\hline & Type 2 & - & $2000-3000$ & - \\
\hline & Type 1 & - & $5000-14,000$ & - \\
\hline
\end{tabular}

Meier (35CO5) is in the Wapato Valley about $4 \mathrm{~km}$ across the Columbia River from Cathlapotle. It was excavated from 1987 to 1991 and contains the remains of a single large "simple" plank house and its associated middens (Ames et al. 1992; Smith 2008; FIG. 4). The house was occupied continuously between ca. A.D. 1400 and 1810 (Ames et al. 1992; Kaehler 2002). The structure $(33 \times$ $14.9 \mathrm{~m}$ ) has an area of $492 \mathrm{sq} \mathrm{m}$, and yielded the most elaborate storage facilities yet identified (FIG. 5).

Herzog (45CLI1) is also in the Wapato Valley, several kilometers south of Cathlapotle on the same Columbia River tributary. It was excavated between 1964 and 1966 by the Oregon Archaeological Society (OAS), an amateur society (Foreman and Foreman 1977). The pit complexes are clearly visible in photographs (FIG. 6), indicating that these features can be hard to miss, even with poor excavation methods. The site's founding date is unknown. Projectile point styles suggest it was occupied within the last 1000 years. The number and kinds of trade goods suggest an abandonment date around the same time as that of the Meier site. Based on an examination of photographs, the site appears to have had three closely adjacent structures or possibly a single large dwelling with compartments.

The St. Johns Site (35MU44/46) is located in the Wapato Valley in an industrial section of Portland, Oregon, adjacent to wetlands that were once extensive. The site was sampled in 2003-2004 (Pettigrew 2005). The excavations exposed a small area containing pits, hearths, and structural features such as posts and plank molds. The exposure was insufficient to determine the full extent of the pit features or their spatial organization. The site is dated between ca. A.D. 150 and 1805 although the bulk of the occupation postdates A.D. 1400 . Of the 17 radiocarbon dates (Pettigrew 2005), 13 are contemporaneous with Cathlapotle. The other four fall between Ca. CAL A.D. 150 and 1000 or so (Pettigrew 2005: table 11-1) and are associated with pits and structural features.

The Bachelor Island (45CL43) site is in the Wapato Valley close to both Herzog and Cathlapotle. It was originally excavated by the OAS in 1967 (Steele 1980). In 2003, a backhoe trench was excavated through the site as part of a geoarchaeological project. Using remote sensing data 


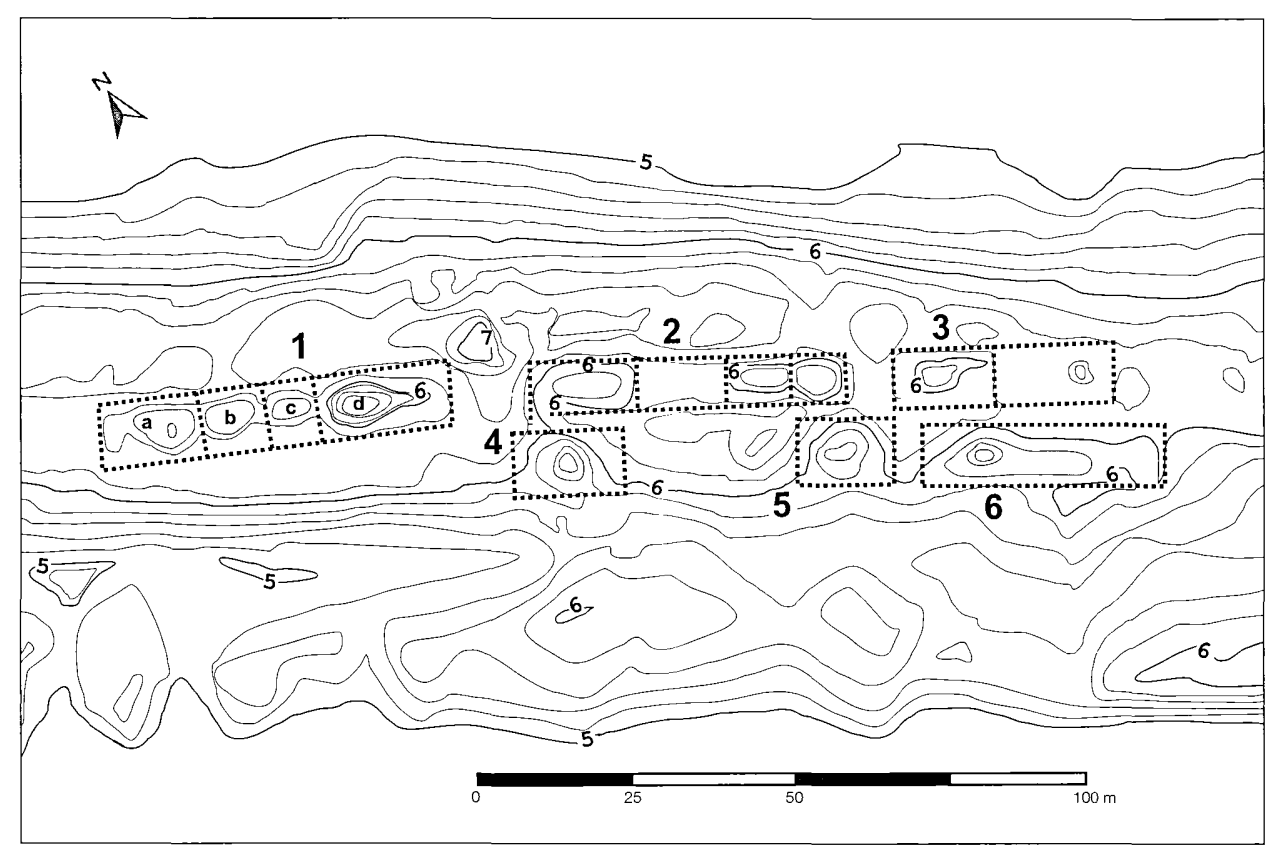

Figure 3. Map of Cathlapotle showing the town layout and illustrating the simple open interior house style (Houses 4 and 5 ) and the compartmented style (Houses 1, 2, and 3). Shaded areas indicate the lowest areas within the house depressions. Letters in House 1 designate compartments, e.g., Hlb.

Contour interval is $20 \mathrm{~cm}$.

(Kendall McDonald, personal communication 2003), the trench was positioned to intersect the OAS excavations. The trench's profile was cleaned and examined by us. The trench exposed two large pit complexes whose cross sections are identical to the ones at Cathlapotle House 1 (FIG. 7), Cathlapotle Houses 2, 4, and 6, and the house at Meier. They also have structural features associated with those houses, such as wall trenches and plank molds (Ames et. al 1992). Eleven radiocarbon dates from both cultural and non-cultural contexts (TABLE 2) span perhaps 600 years between about 500 CAL B.C. and CAL A.D. 100. The bulk of the cultural dates, however, cluster very tightly between about 300/200 CAL B.C. and 50 CAL B.C. suggesting the occupation was relatively short, perhaps 200 years.

\section{The Pit Complexes}

The Meier pits are the best understood and the most elaborate. They were originally constructed as a pair of long, open, voluminous trenches aligned on the house's long axis between the hearth row and the sleeping platforms. The trenches are 1-2 $\mathrm{m}$ deep and roughly as wide. The total volume of the trenches is estimated to be $127 \mathrm{cu}$ $\mathrm{m}$ (TABLE I), or $11 \%$ of the house's $1422 \mathrm{cu} \mathrm{m}$ total volume (Ames 1996). The two trenches joined between the hearths, which, as a result, sat on platforms within the trench complex. At the house's north end, the joined trenches created a flat open area beneath the house floor between the hearth and the dwelling's north wall. We do not know whether the trenches also merged at the house's southern end. They are deepest there. Given the complex's full extent and size, we feel justified in calling the trenches a "cellar."

The cellar was originally dug through a silt loam into Pleistocene gravels. When encountered archaeologically it contained a complex fill. Originally the cellar was free of fill and was part of the house's original fittings. It was not created as a consequence of continual reexcavation of individual pits by the house's residents, but was dug out as a single unit. It would have been covered with a plank floor. Five lines of evidence support these inferences. First, a pathway on the cellar floor initially ran along the edge of the trench for at least $15 \mathrm{~m}$ giving access to the cellar's contents (FIG. 5). At some point, the cellar was filled with earth. As it filled, the pathway was maintained until it was packed with thermally-altered rock and capped with a clay floor. Postholes, post molds, and plank molds (Ames et al. 1992) are present on the cellar floor. Circular earthen rims (FIG. 5) were constructed on the cellar floor, suggesting the need to support or reinforce freestanding containers. These rims average $76 \mathrm{~cm}$ in diameter, about the reported size of storage baskets (Ames et al. 1992), and mean depth is 34 $\mathrm{cm}$. The rims were made of reworked fill, a slurry of the 

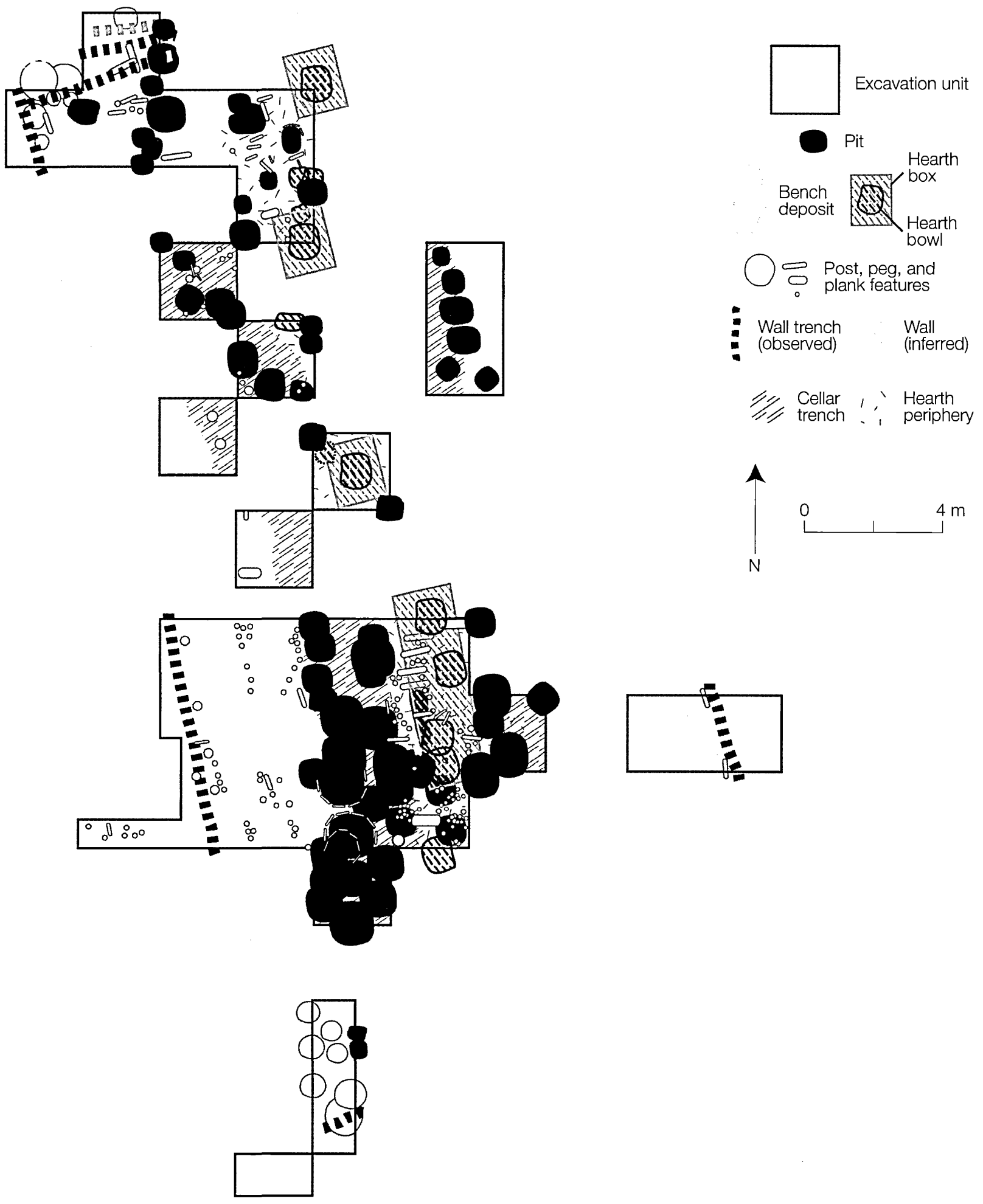

Figure 4. Map of the Meier excavations showing the distribution of pits within the trench complexes. 


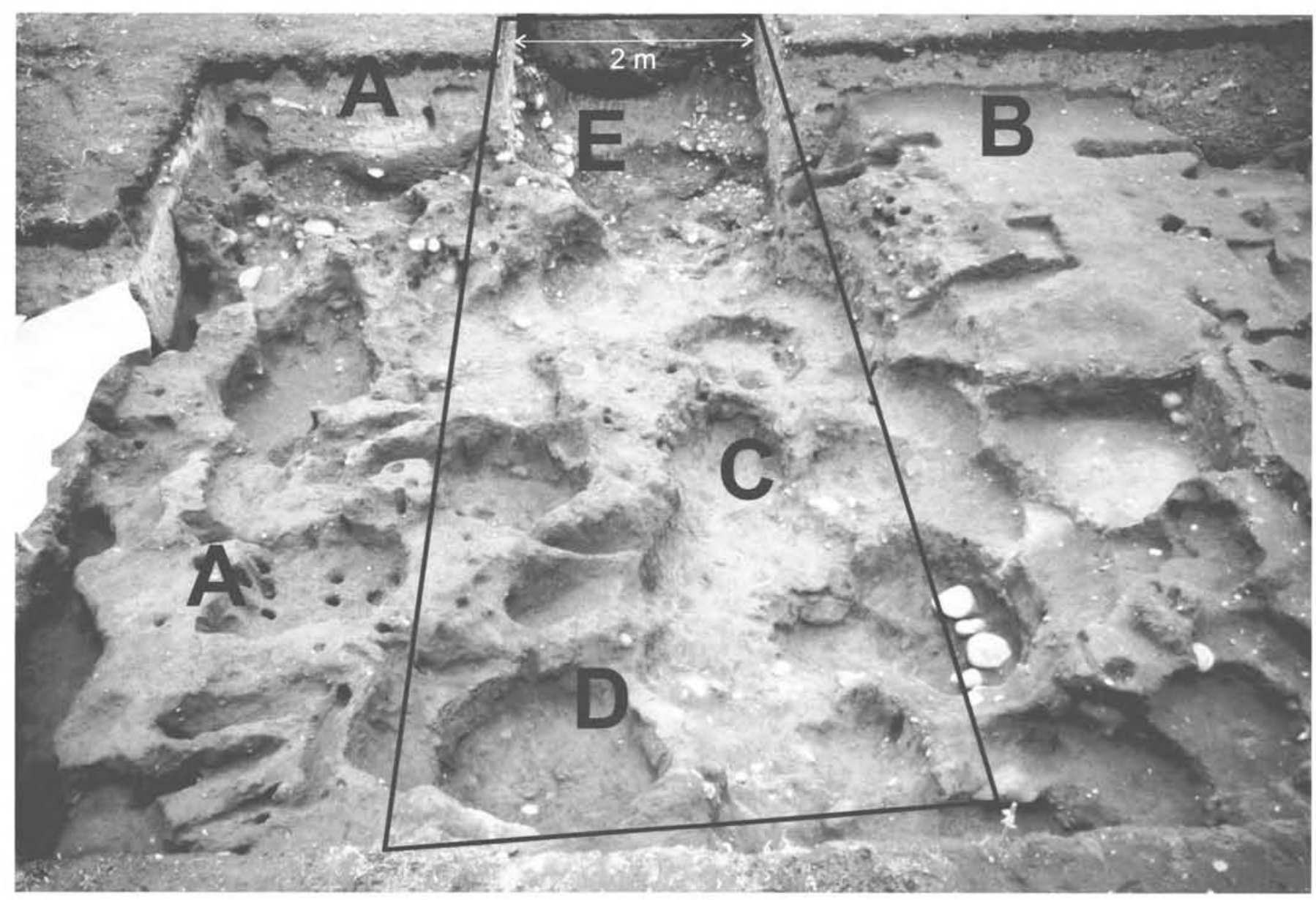

Figure 5. View of the Meier excavations looking south across the large excavation block in the lower left portion of Figure 4. The rectangle encloses most of the cellar trench in the excavation block. A) hearths; B) bench; C) the end of the cellar path; D) constructed earthen rim; E) the location of the wooden rims.

silt-clay loam and pit/cellar fill (Ames et al. 1992). Lastly, circles of multiple overlapping small post and plank molds (FIG. 5) were present at the south end of the cellar. These probably represent wooden supports, replaced at least four times, for soft, full containers.

Radiocarbon dates from the cellar floor and associated features visible in Figure 5 indicate that the floor dates to the 1400s and was free of fill for at least a century. The stratigraphy of the cellar fill suggests that the bulk of excavated fill was the last of perhaps two episodes in which the cellar became partially or completely filled. As the cellar filled, house residents dug and redug pits into this fill. In previous episodes, the cellar was cleaned out and remained open for some time before it filled again. The removed fill was probably dumped in the site's midden. Our radiocarbon dates (Ames et al. 1992) suggest that the fill we excavated began accumulating after around CAL A.D. $1650-1700$. As noted above, the plank floor was eventual- ly abandoned and the fill was capped with a clay floor. This occurred before European contact. Pit digging continued, however, through the clay floor. Pit position was stable; pits were redug (renewed) in the same place many times. Presumably, they were covered, possibly with small planks.

Individual pits had flat or bowl-shaped bottoms with vertical side walls. In addition to the constructed and planked rims, a small number were lined with burnt grass and shell, probably the result of processing something. Others were lined with thermally-altered rock and/or grav$\mathrm{el}$. Thermally-altered rock, cobbles, and boulders were also placed beneath posts.

Turning to Cathlapotle, we exposed pit complexes in four structures and extensively sampled them in two. All sampled structures had trenches beneath their sleeping platforms rather than between the platforms and hearths. No instance was found at Cathlapotle where the trenches merged between hearths. The profile of our hand-excavat- 


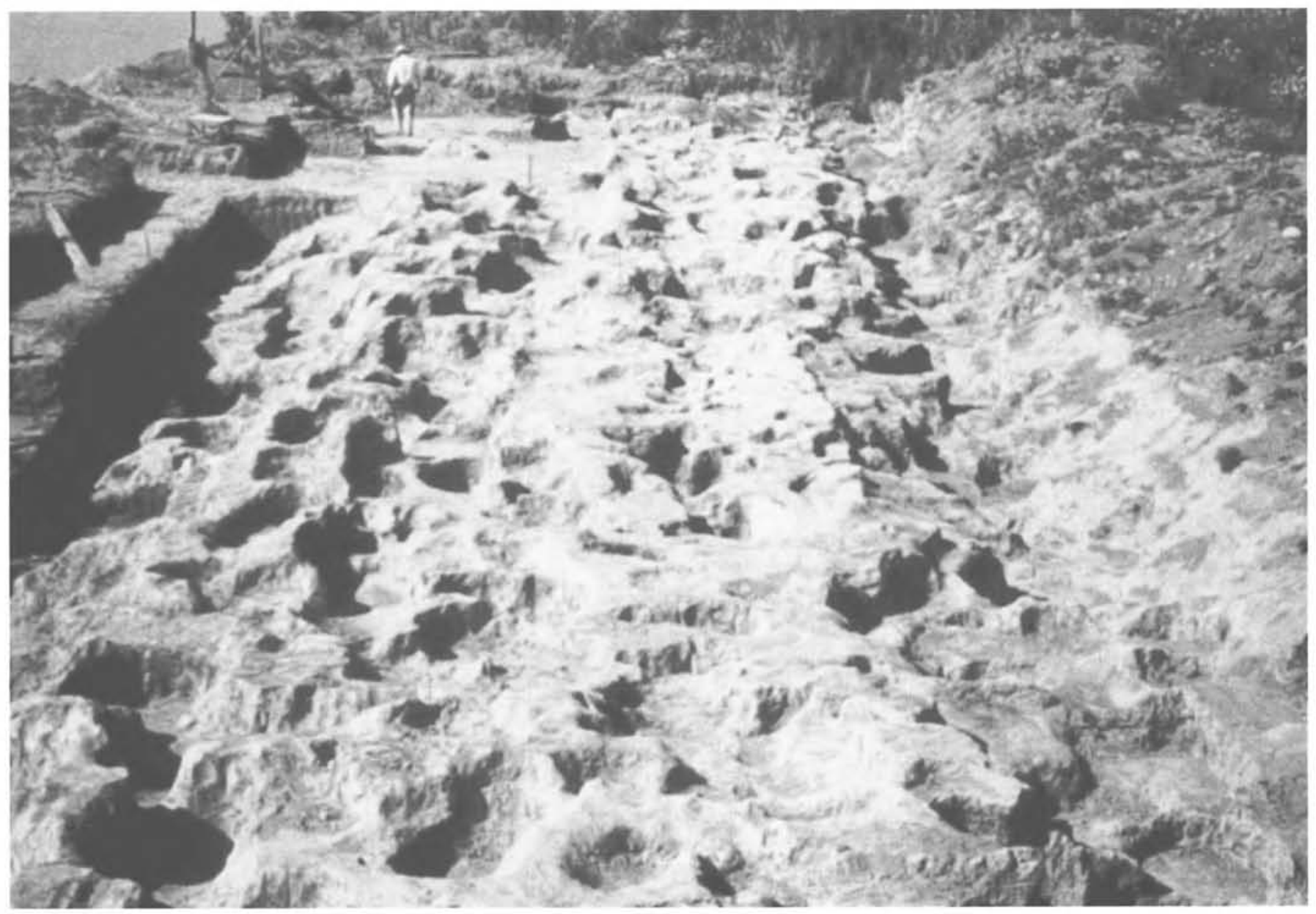

Figure 6. Herzog excavation, looking north, showing the positions of the pit complexes. Photo courtesy of the Oregon Archaeological Society.

ed trench bisecting House 1 (FIG. 7) illustrates the typical cross-section of these structures, with the parallel pit-complex trenches flanking the raised central platform with hearths. The trenches were 1 to $2 \mathrm{~m}$ wide and 1 to $2 \mathrm{~m}$ deep with a very dark, organic fill. As at Meier, the trenches were dug as part of the initial construction of the houses, though they seem to have been rarely completely free of fill.

Archaeologically, the trenches are complexes of pits running the full length of the house next to the house wall. In fact, they extend to within a few centimeters of the walls. The Cathlapotle pits have flat or bowl-shaped bottoms and more-or-less vertical walls, although some are bell-shaped, expanding at the bottom. This is probably the result of continuous re-digging. None of the variant forms present at Meier were encountered at Cathlapotle. Viewed from above, the pit complexes appear as multiple intersecting pit rims; in profile they appear as a series of interbedded pits
(FIG. 7). The Cathlapotle pits are smaller than those at Meier. Mean diameter is $59 \mathrm{~cm}(15-250 \mathrm{~cm})$ and mean depth is $28 \mathrm{~cm}(2-108 \mathrm{~cm})$ although the largest individual pits encountered were exposed at Cathlapotle.

The distribution of pits and trenches in House 1 is different among its three sampled compartments. House 1 is the largest compartmented house at Cathlapotle. Pit complexes are present against both east and west walls in Compartment ld, the largest and most southerly compartment, but they do not appear to be present along the west walls of Compartments $1 \mathrm{~b}$ and $1 \mathrm{c}$. Compartment $\mathrm{la}$ has not been sampled. The east wall pit complexes in these latter compartments are not as deep or as wide as those in Compartment $1 \mathrm{~d}$. The three compartments were built at the same time (Ames et al. 1999). The trenches at Cathlapotle are not as commodious as those at Meier (TABLE I) but they are still capable of holding large volumes of material.

The Herzog house(s) apparently had clay floors, with 
Table 2. Radiocarbon dates for the Bachelor Island Site.

\begin{tabular}{|c|c|c|c|c|}
\hline Context & Laboratory no. & Date $\pm 1 \sigma$ & 2- $\mathrm{c}$ calibrated age span* & Probability \\
\hline \multicolumn{5}{|l|}{ Cultural contexts } \\
\hline Near House 2 & Beta-195955 & $2390 \pm 40$ & 554 в.с. -389 в.с. & 0.85 \\
\hline - & Beta- 195950 & $2170 \pm 40$ & 369 в.с. -106 в.с. & 1.00 \\
\hline Pit near House 1 & Beta-195951 & $2130 \pm 40$ & 231 в.c. -46 в.с. & 0.83 \\
\hline Interior, House 2, floor? & Beta-195948 & $2120 \pm 40$ & 211 в.C. -42 в.с. & 0.89 \\
\hline Shell midden, between houses & Beta-195954 & $2120 \pm 40$ & 211 B.c. -42 B.c. & 0.88 \\
\hline Pit near House 2 & Beta-195956 & $1940 \pm 40$ & 44 B.C.-A.D. 135 & 1.00 \\
\hline \multicolumn{5}{|l|}{ Non-cultural contexts } \\
\hline - & Beta- 195953 & $2460 \pm 40$ & 670 B.C. -412 в.C. & 0.74 \\
\hline- & Beta-195052 & $2334 \pm 40$ & 521 в.с. -354 в.с. & 0.90 \\
\hline- & Beta-204746 & $2090 \pm 40$ & 203 B.C. - A.D. 1 & 0.99 \\
\hline - & Beta-195957 & $2000 \pm 40$ & 111 B.C.-A.D. 83 & 0.99 \\
\hline- & Beta-204757 & $2000 \pm 40$ & 111 в.C.-A.D. 83 & 0.99 \\
\hline
\end{tabular}

the pits penetrating the floors. The majority of pits were aligned in trenches along the long axes of the houses (FIG. 6) by the house walls (analogous to Cathlapotle). Pits also were also distributed across the house floor, as at Meier. We have no information on hearths. Also similar to Meier, earthen and plank rims were constructed. There were also caches of artifacts and raw materials including digging stick handles and net weights. Herzog is important for two reasons: it confirms details, such as the rims and caches, observed at either Meier or Cathlapotle, and it demonstrates that these features are hard to miss when encountered in large scale excavations, even by poorly trained excavators.

The Clahclellah complexes are the simplest. They are parallel rows of individual pits aligned along the houses' long axes flanking single hearths rather than trenches. They were maintained and reexcavated through at least three rebuilding episodes. The pits appear to have been basins with vertical or sloping walls. While significantly smaller than the trenches and pit complexes at the sites already described, the pits added significantly to the available storage space (TABLE I).

At present, the St. Johns and Bachelor Island sites are important for the evidence they provide for pit chronology. Prior to acquisition of their radiocarbon dates, the known pit complexes were dated to the last 500 years (Ames et al. 1992, 1999). Bachelor Island clearly demonstrates the complexes are as old as 2000 years (see below) while the St. Johns site may fill the temporal gap of dated complexes between Bachelor Island and Meier, Cathlapotle, and Clahclellah.

\section{Pit Contents}

The pits were used for storing food and non-food items (Kent 1999). Their contents are particularly rich in plant (D. Ann Trieu Gahr, personal communication 2006) and fish remains (Butler 2002; Virginia Butler, personal com- munication 2006; Gay Frederick, personal communication 2007) but they also produced many terrestrial and aquatic mammal remains (Lyman and Ames 2005). Additionally, they were used to store everything from high status goods such as iron daggers and copper pendants to caches of broken tools and raw materials for antler and chipped stone tools (Butler 2007; Banach 2002; Davis 1998; Hamilton 1994; Kaehler 2002; Smith 2004; Wolf 1994). They were also used for storing debris such as thermally-altered rock, lithic waste, and exhausted lithic tools prior to disposition in the sites' middens (Smith 2006, 2008).

\section{Spatial and Temporal Distribution}

The pit complexes are present in permanent houses in sites in the Wapato Valley and Columbia Gorge. Houses at the three sites (FIG. I) in the GLCR that lack pit complexes appear to be temporary dwellings. One site, Broken Tops (35MU57) in the Wapato Valley, contained two small post and beam buildings lacking pits, hearths, and benches, and had limited sheet trash deposits (Wilson 1994). The site was contemporary with the Precontact occupations at Meier and Cathlapotle. It may have been occupied seasonally (Ellis and Fagan 1993) or by a low status household (Ellis 2006). A site on Willapa Bay north of the Columbia River's mouth had two structures with central hearths but neither pits nor sleeping platforms. This site, 45PCl01 (DePuydt 1994), was seasonally occupied and is late in date. Station Camp/McGowan is located on the Columbia River just above its mouth and dates between Ca. CAL A.D. 1790 and perhaps 1820 (Wilson and Cromwell 2005). It contains a number of plank house structural features, including post molds, plank molds, burnt planking, wall trenches, hearths, and a few small pits. Neither the hearths nor the pits are aligned and there is no evidence for sleeping platforms. Excavated houses along the north Oregon coast sometimes have internal pits, but these are not as 


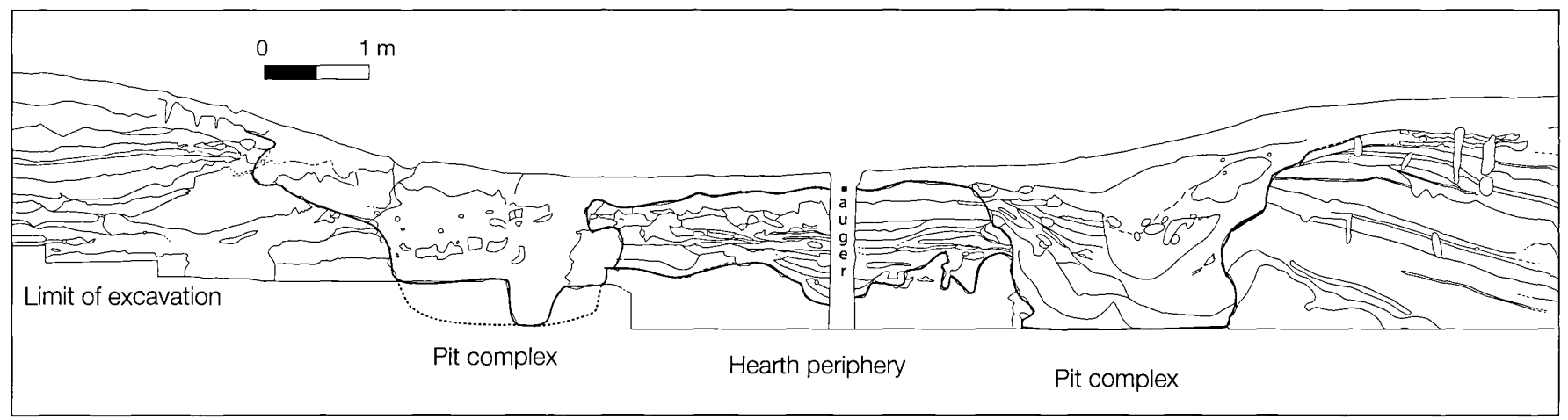

Figure 7. Schematic of the south wall of the excavation through Cathlapotle House 1 illustrating the typical shape of the trench complexes in profile.

voluminous or organized in rows as in the GLCR sites (Losey 2002).

There are two very important sites with houses where it is currently impossible to determine if pits were present. The Palmrose site is on the northern Oregon Coast and the Kersting site is in the Wapato Valley (FIG. I). Palmrose is a shell midden containing a relatively large rectangular house with either a single long central hearth or multiple central hearths. It is among the earliest documented rectangular houses on the far southern Northwest Coast (Ames and Maschner 1999) with radiocarbon dates spanning ca. 800 CAL B.C. to CAL A.D. 300 (Connolly 1992). The Kersting site is on the same tributary of the Columbia River as Herzog and Cathlapotle. It contains several small structures dating to ca. 2000 B.P. (uncalibrated radiocarbon years before A.D. 1950) (Jermann, Lewarch, and Campbell 1975).

The GLCR pit complexes have virtually no parallel on the Northwest Coast or Intermontane Plateau of North America. The only other extensive interior storage pits on the Northwest Coast of which we are aware are at the Kitwanga Fortress site in northern British Columbia (MacDonald 1984, 1989), where food was stored in anticipation of attacks and sieges. Kitwanga appears to date to the fur-trade era. Many excavated prehistoric Northwest Coast houses are in shell middens. It is possible that pit complexes could be missed in shell midden excavations given their stratigraphic complexity. Small-scale excavations could exacerbate the difficulties. In the GLCR the pits were only exposed by large-scale block excavations in alluvial sites, and were not recognized at one of these sites in a previous excavation using small $(50 \times 50 \mathrm{~cm})$ test units. These pits are hard to miss, however, in excavations of even moderate scale and there is now an extensive record of excavated houses elsewhere on the Northwest Coast spanning 4000 years, none of which produced these complexes.

Interior and exterior storage pits and other storage fa- cilities are also known from the Intermontane Plateau of Nw North America, but no similar pit complexes. Keatley Creek in south central British Columba is a well-known example (Hayden 1997) where storage pits are found in semi-subterranean pithouses. These pits are generally, although not always, close to the house walls, hence under sleeping platforms, but they do not form pit complexes, nor do they have consistent spatial patterning like those in the GLCR.

Farther afield, houses on Kodiak Island and adjacent portions of Alaska's Pacific coast have subfloor storage pits (Hoffman 1999) as well as large basin-like pits associated with their hearths. These hearths may have been roasting or cooking facilities. There is no suggestion that the GLCR features were used in this way. These houses also have small chambers which may have been for storage or sleeping away from the main structure but linked to it by tunnels. These houses date within the last millennium (Hoffman 1999).

The closest parallels in organization and size we could find to the GLCR pits are the trenches flanking Bandkeramik (Danubian) houses in Germany (Bradley 2001; Gronenborn 1999). We do not know their contents, but they parallel the houses' long axes next to the walls. These trenches, however, are located outside the structures.

\section{Storage Potential}

Here we discuss the storage potential represented by these complexes using "storage potential" (Christakis 1999) to estimate the space available for storage, regardless of whether the space was always used that way or was the final use. There is evidence for use of "pit features", including extensive complexes and sometimes very large pits, by hunter-gatherers and low-level food producers since the Upper Palaeolithic (Soffer 1989). Two datasets provide useful comparisons to the features in the GLCR: the vol- 
ume of interior pits exposed at the Keatley Creek site in south-central British Columbia (Hayden 2000b), and the storage spaces in a sample of historical and Bronze Age sites on the island of Crete (TABLE I). These are, respectively, a hunter-gatherer dataset and an agriculturalist dataset. The Keatley Creek data include total storage volume and storage volume per sq $\mathrm{m}$ of floor space.

Keatley Creek has been central to the development and testing of Brian Hayden's theories about the origins of social inequality in intermediate societies (Hayden 1997). The site has 119 visible pithouse depressions, as well as an equal number of smaller depressions, many of which may be storage or roasting pits (Hayden 2000a, 2000b, 2004). Variation in depression sizes led Hayden to hypothesize the existence of significant status differences among households. The site's location provides access to major salmon runs whose harvesting would have provided the surpluses required for the development of social inequality (Hayden 1995). Hayden's excavations focused on four pithouses with interior storage pits (TABLE I). The storage potential of the Keatley Creek houses overlaps that of the Clahclellah houses but is many times smaller than the storage potential of the Meier or Cathlapotle houses. For example, Meier's storage volume is 16 times greater (or 3.685 times greater if comparing liters per sq $\mathrm{m}$ for each) than that of House 7, a high status dwelling at Keatley Creek. The interior pits at Keatley Creek probably provide a minimum estimate of the storage potential at that site, given the presence there of exterior pits, but our discussion does not include the exterior pits at Meier or at Cathlapotle either.

Kostas Christakis' data for Bronze Age and early historical Crete (Christakis 1999) are the most readily available evidence for storage potential in stratified, agricultural societies (TABLE I). Christakis measured storage potential in two household samples from Crete: 620 rural village houses dating between A.D. 1898 and 1940, and 70 Neopalatial phase (1700-1450 B.C. [Adams 2006]) Minoan houses (TABLE I). Clahclellah storage pits are equivalent in volume to some Cretan houses in both samples. Meier and Cathlapotle House 1 pit complexes far exceed the largest Cretan storage structures, including those of the palace-like Bronze Age dwellings. The largest single pits at both Meier and Cathlapotle have larger storage potentials than the total potential storage volume of the Type 1 Minoan houses. Since a great deal of household storage in the GLCR was in the rafters of the houses, these estimates are minimal. Our point is that our pit complexes are the same size if not larger than those found in intensive state-level Bronze Age and modern economies.

It might be argued the GLCR facilities were large because the households were very large, larger than those of
Cretan farmers, for example. Ames (in press) estimates the size of the Meier household at 203 people, who would indeed require a lot of stored food. One of the major dietary staples in the Wapato Valley was wapato (Sagitteria latifolia), a wetland plant with a nutritious root. Ames (in press) calculated that the 203 people at Meier would require 26 metric tons of wapato a year assuming it represented $20 \%$ of their annual diet (Darby 1996). Twenty-six metric tons of wapato would occupy about $26 \%$ of the pit volume of the Meier house. If the storage potential under Meier's roof is included ( 907,000 liters), the wapato requires only $3.2 \%$ of the house's total storage potential $(1,034,000 \mathrm{cu}$ liters). While the wapato estimate requires considerable refinement, it suggests a significant capacity for surplus storage. The potential role of the cellars in wapato storage is suggested by ethnographic evidence that neighbors of the Chinookans to the south in the Willamette Valley stored wapato in pits four to five feet deep (Zenk 1976).

Elsewhere, including in the SE United States (DeBoer 1988; Wesson 1999) and Japan (Atsuko Miyaji, personal communication 2003), shifts between interior and exterior storage pits have been linked to shifts in elite power and to household and community control of stores. These arguments suggest that household elites controlled GLCR stores because the pits appear to be household or house compartment features. They vary in size within the houses but do not cluster together and are not randomly dispersed. They are uniformly distributed along the pit row or trench (Butler 2007). For analytical purposes, Northwest Coast archaeologists partition house interiors into "hearth groups" assuming one or two extended families per hearth (Grier 2001). The ethnographic literature supports this assumption. Each large GLCR house had a row of hearths along its midline. Meier's row had five or more hearths; House Compartment Id at Cathlapotle had three. The hearths varied in ways suggesting they were functionally specialized. For example, Meier's southernmost hearth was a large $(3 \times 2 \mathrm{~m})$, high heat facility, while the northernmost one was much smaller and cooler. The pits were deepest near the southern hearth but they did not cluster near the hearths (Butler 2007) as they might if they were associated with families. These general patterns also apply to Cathlapotle. From this, we infer these features and perhaps their contents were controlled at the household level rather than by individual families or by the larger community.

Domestic storage pits have also been encountered in Colonial period slave house sites in Virginia (Fraser Neiman, personal communication 2005; Samford 1996) and Tennessee (Young 1995). Neiman develops a model relating them to patterns of slave household recruitment and organization, arguing that sub-floor storage facilities 
are "safety deposit boxes" that facilitate monitoring of personal goods, including food, by making it more difficult to access them. He argues that the facilities are associated with large slave quarters in which people had no control over household membership. Neiman's model is intriguing. The GLCR had high numbers of slaves in the early 19th century (Donald 1997; Hajda 2005.) and perhaps before contact (Ames in press). Thus, non-elite household members might have had little control over household membership. In the southern slave quarters, however, the pits were separate from each other, requiring separate access. In the GLCR, there was access along their full length. The pathway at Meier made the entire facility accessible beneath the house floor.

Why were pits used, given the overall storage potential of the GLCR structures (Ames 1996)? It is clear from the documentary evidence (Sobel 2004) that large volumes of stores could be suspended in the spaces below the house rooves. Illustrations of other Northwest Coast houses show boxes and baskets stacked on the sleeping platforms. The Columbia River flooded regularly with high water in late spring and early summer. GLCR sites were at or just above the mean annual flood level (O'Rourke 2005). The Meier site was not regularly inundated because it was some distance from the Columbia River, but Cathlapotle was flooded regularly. Other major Chinookan towns in the Wapato Valley would also have suffered flooding. The storage facilities and their contents must have often been wet if not actually inundated. Despite this, the houses were built and rebuilt with these facilities over at least two millennia. One possible answer is that the pits represent an effort to conceal how much was stored. A more prosaic possibility is that some essential resources, such as wapato, kept better underground.

\section{Conclusions}

The GLCR pit complexes are significant for at least four reasons: their size, their interior location, their spatial organization, and their association with the kind of subsistence economy Smith (2001) terms "low-level production." The pit complexes are very large and add significantly to the storage potential of the houses containing them. The complexes could have begun as open trenches covered by flooring, but may sometimes have resulted from the regular digging of pits over long periods of time. The very standard spatial organization coupled with the fact that they are interior pits suggests that the pits and their contents were controlled by households or household elites, rather than by individual families or communities. The features are currently known only from permanent houses (Hajda 1994) in the central and eastern portions of the
GLCR. They are absent in temporary structures. They appear to have been basic features of permanent houses in this region for ca. 2000 years and reflect a considerable effort in initial construction, maintenance, and management. The pits have no clear parallels in their scale and spatial organization on the Northwest Coast or in western North America. While large-scale storage facilities are known for some hunter-gatherer groups, they are unusual and lack the rigid spatial organization found here. There are a number of possible reasons for this relative rarity. They may be unusual in part because hunter-gatherer storage facilities tend to have low archaeological visibility as a consequence of their construction (e.g., exterior racks or stands indicated only by ambiguous posthole patterns) or their distribution across the landscape (remote caches). They may be unusual because, as Warren DeBoer (1988) suspects, many storage pits have been "ignominiously" labeled rubbish pits and therefore not reported. It may also be because even when identified as storage pits, pits are often poorly described. We found it difficult to find pit numbers, dimensions, or spatial distributions reported consistently or even at all. One of our hopes for this publication is that it will encourage other researchers to send us references or comparable data. Finally, large-scale facilities like these may actually be relatively rare among hunter-gatherers or low level food producers (Smith 2001) because they seldom produced and managed stores at the scale indicated by the Wapato Valley facilities. We believe these production levels were not at all unusual, although demonstrating that is well beyond the scope of this paper. What may be unusual about the Wapato Valley is how stores were controlled and used within large, long-lived households.

In any case, the scale of these features and the investment in them suggest sustained levels of surplus production equivalent to at least some agriculturalists. If our ongoing studies confirm this inference, it has important implications for our understanding of what constitutes "lowlevel food production" and for the relationships between surplus production and the evolution of social complexity. Our evidence indicates low-level food producers can produce and manage a considerable amount of stored food. The presence/absence of domesticates is central to Bruce Smith's distinctions among food procurement, low-level food production, and agriculture (Smith 2001). Our point here is not at all to quibble with Smith; rather to argue that domesticates are not required for sustained production of large volumes of stores. Rather, the key issues are the scale of production and its relationship to the political economy. We raise this point not because it is new to us-it is notbut because the long-standing intellectual linkage between agriculture and social complexity remains quite strong. 
Scholars continue to be startled at evidence for high levels of production and social complexity in the absence of farming or domesticates.

We noted in the introduction that the direct causal linkages among storage, social inequality, and complexity have been decoupled although it is generally accepted that "surplus" production is necessary. That leaves unaddressed questions about how complexity is actually financed and sustained by these economies. What levels of sustained production are necessary for complex social systems to persist, and are there forms of productive organization that are more likely to last than others? The visibility, scale, and spatial organization of the Wapato Valley pit features draw attention to these issues.

\section{Acknowledgments}

The Meier and Cathlapotle excavations are part of the Wapato Valley Archaeological Project by Portland State University Field Schools; the Station Camp excavations were a Phase III cultural resource management project; and the Bachelor Island project was part of an ongoing United States Fish and Wildlife Service (USFWS) project on the geoarchaeology of the Columbia River floodplain. We thank the Confederated Tribes of the Grande Ronda for their interest in the Meier project and the Chinook Tribe, particularly former tribal chair, Gary Johnson, for their interest, involvement, and support. We also thank Don Meier, former owner of the Meier site property, for his support. The Cathlapotle and Bachelor Island projects were initiated by the USFWS. We especially thank the Regional Archaeologist's office and Anan Raymond, USFWS Regional Archaeologist, for their interest and support in local and regional archaeology. Our ongoing work on the USFWS' Ridgefield Wildlife Refuge relies on the assistance of many USFWS employees, whom we thank.

The excavations and analyses were funded and/or assisted by the Friends of the Wapato Valley, Jean and Ray Auel, the National Endowment for the Humanities, the National Park Service, the National Science Foundation, Portland State University, Simon Fraser University, the University of Michigan, the University of Missouri-Columbia, the University of Southern Illinois, and the USFWS. Douglas Wilson, NPS archaeologist, directed the Station Camp excavations. Richard Pettigrew graciously provided access to the Lombard Street project so we could examine the features.

Our understanding of these features benefited from discussions with William Cornett, Steven Hamilton, Doria Raetz, Elizabeth Sobel, and John Wolf. Other colleagues contributing insights and knowledge include Robert Boyd, Virginia Butler, David Ellis, John Fagan, Ann Trieu Gahr,
Charles Hodges, R. Lee Lyman, Richard Pettigrew, and Douglas Wilson. James O'Connor, USGS, provided insights at Bachelor Island. Tom Connolly and James Chatters provided photographs of Palmrose and Kersting respectively. The Oregon Archaeological Society kindly extended permission to use their photographs of the Herzog excavations. We particularly thank Harvey Steele for his help. Clive Bonsall, Clive Gamble, Fraser Neiman, Max Pavesic, Peter Rowley-Conwy, Olga Soffer, Clive Waddington, and Marek Zvelebil assisted us with information and sources in our quest for comparative materials on storage pits. We thank Tom Connolly, Gary Coupland, and Brian Hayden who improved the paper through their comments on an earlier draft.

Kenneth M. Ames (Ph.D. 1976, Washington State University) is Professor and Chair of the Department of Anthropology at Portland State University and has been conducting research in western North America and the Pacific Rim since 1968. His research focuses on the evolution of social complexity and hunter-gatherers. Mailing address: Department of Anthropology, Portland State University, Portland, OR 97207. E-mail: amesk@pdx.edu

Cameron McP. Smith (Ph.D. 2004, Simon Fraser University) is an Adjunct Assistant Professor at Portland State University. His dissertation research included site formation processes at Meier and Catblapoltle as well as microscopic usewear analysis.

Alexander Bourdeau (M.A. 1979, University of Montana) is an archaeologist with the United States Fish and Wildlife Service. He has been involved in geoarchaeological research along the lower Columbia River for the last 10 years. He organized the test excavations at the Bachelor Island site.

Adams, Ellen

2006 "Social Strategies and Spatial Dynamics in Neopalatial Crete: An Analysis of the North-Central Area," American Joumal of Archaeology 110: 1-36.

Ames, Kenneth M.

1981 "The Evolution of Social Ranking on the Northwest Coast of North America," American Antiquity 46: 789-805.

1995 "Chiefly Power and Household Production on the Northwest Coast," in T. Douglas Price and Gary M. Feinman, eds., Foundations of Inequality. New York: Plenum Press, 155-187.

1996 "Life in the Big House: Household Labor and Dwelling Size on the Northwest Coast," in Gary Coupland and Edward B. Banning, eds., People Who Lived in Big Houses: Archaeological Perspectives on Large Domestic Structures. Monographs in World Prehistory Vol. 27. Madison: Prehistory Press, 131-150.

in press "Slavery, Household Production and Demography on the Southern Northwest Coast: Cables, Tacking and Rope- 
walks," in Catherine Cameron, ed., Invisible Citizens: Captives and Their Consequences. Salt Lake City: University of Utah Press.

Ames, Kenneth M., and Herbert D. G. Maschner

1999 Peoples of the Northwest Coast: Their Archaeology and Prehistory. London: Thames and Hudson, Ltd.

Ames, Kenneth M., Doria F. Raetz, Stephen Hamilton, and Christine McAfee

1992 "Household Archaeology of a Southern Northwest Coast Plank House," Journal of Field Archaeology 19: 275-290.

Ames, Kenneth M., Cameron M. Smith, William L. Cornett, Elizabeth A. Sobel, Stephen C. Hamilton, John Wolf, and Doria Raetz

1999 Archaeological Investigations at 45CLI (1991-1996) Ridgefield Wildlife Refuge, Clark County, Washington: A Preliminary Report. Cultural Resources Series 13. Portland, OR: U. S. Department of the Interior, Fish and Wildlife Service Region 1.

Arnold, Jeanne E.

1996 "The Archaeology of Complex Hunter-Gatherers," Journal of Archaeological Method and Theory 3: 77-126.

Banach, Patricia K.

2002 "Copper on the Pacific Northwest Coast," unpublished M.A. thesis, Portland State University.

Binford, Lewis R.

2001 Constructing Frames of Reference: An Analytical Method for Archaeological Theory Building Using Hunter-Gatherer and Environmental Data Sets. Berkeley: University of California Press.

Boyd, Robert T.

1990 "Demographic History, 1774-1874," in Wayne Suttles, ed., Handbook of North American Indians, Vol. 7, The Northwest Coast. Washington D.C.: Smithsonian Institution, 135-148.

1999 The Coming of the Spirit of Pestilence: Introduced Infectious Diseases and Population Decline among Northwest Coast Indians, 1774-1874. Seattle: University of Washington Press.

Boyd, Robert T., and Yvonne P. Hajda

1987 "Seasonal Population Movement Along the Lower Columbia River: The Social and Ecological Context," American Ethnologist 14: 309-326.

Bradley, Richard

2001 "Orientations and Origins: A Symbolic Dimension to the Long House in Neolithic Europe," Antiquity 75: 50-56.

Bursey, Jeffrey A.

2001 "Storage Behavior in the Northeast: A Review of the Evidence," North American Archaeologist 22: 179-199.

Butler, Virginia L.

2002 Fish Remains from Cathlapotle: Preliminary Report. Portland, OR: Portland State University.

Butler, Stephanie T.

2007 "The Interpretation of Indoor Storage Facilities from Two Plank House Sites in the Greater Lower Columbia River Region," unpublished M.A. thesis, Portland State University.

Christakis, Kostas S.

1999 "Pithoi and Food Storage in Neopalatial Crete: A Domestic Perspective," World Archaeology 31: 1-20.

Connolly, Thomas J.

1992 Human Responses to Change in Coastal Geomorphology and Fauna on the Southern Northwest Coast: Archaeological Inves- tigations in Seaside, Oregon. University of Oregon Anthropological Papers 45. Eugene: University of Oregon.

Darby, Melissa Cole

1996 "Wapato for the People: An Ecological Approach to Understanding the Native American Use of Sagittaria latifolia on the Lower Columbia," unpublished M.A. thesis, Portland State University.

Davis, Debra

1998 "Bone Tool Technology: Measurements of Curation and the Spatial Distribution of Bone and Antler Artifacts from a Pacific Northwest Plankhouse," unpublished M.A. thesis, Portland State University.

DeBoer, Warren R.

1988 "Subterranean Storage and the Organization of Surplus: The View from Eastern North America," Southeastern Archaeology 7: 1-20.

DePuydt, Raymond, editor

1994 Data Recovery Excavations from Site 45PC101, Pacific County, Washington. Eastern Washington University Reports in Archaeology and History 100-179. Cheney: Archaeological and Historical Services, Eastern Washington University.

Donald, Leland

1997 Aboriginal Slavery on the Northwest Coast of North America. Berkeley: University of California Press.

Ellis, David V.

2006 "Of a More Temporary Cast: Household Production at the Broken Tops Site," in Elizabeth A. Sobel, D. Ann Trieu Gahr, and Kenneth M. Ames, eds., Household Production on the Northwest Coast. Archaeology Series 16. Ann Arbor: International Monographs in Prehistory, 120-139.

Ellis, David V., and John L. Fagan

1993 Data Recovery Excavations at Broken Tops Site (35MU57). Archaeological Investigations Northwest Report No. 31. Portland: Archaeological Investigations Northwest.

Foreman, Cam, and Dave Foreman

1977 Herzog. Oregon Archaeological Society Report No. 3. Portland: Archaeological Society.

Gallant, Thomas W.

1991 Risk and Survival in Ancient Greece. Stanford, CA: Stanford University Press.

Grier, Colin

2001 "The Social Economy of a Prehistoric Northwest Coast Plank House," unpublished Ph.D. dissertation, Arizona State University, Tempe.

Gronenborn, Detler

1999 "A Variation on a Basic Theme: The Transition to Farming in South Central Europe," Journal of World Prehistory 13: 123-210.

Hajda, Yvonne

1984 "Regional Social Organization in the Greater Lower Columbia, 1792-1830," unpublished Ph.D. Dissertation, University of Washington.

1994 "Notes on Indian Houses of the Wapato Valley" Northwest Anthropological Research Notes 28: 177-188.

2005 "Slavery in the Greater Lower Columbia Region," Ethnobistory 52: 563-588.

Hamilton, Stephen C.

1994 "Technological Organization and Sedentism: Expedient Core Reduction, Stockpiling, and Tool Curation at the 
Meier Site (35CO5)," unpublished M.A. thesis, Portland State University.

Hayden, Brian

1995 "Pathways to Power: Principles for Creating Socioeconomic Inequalities," in T. Douglas Price and Gary M. Feinman, eds., Foundations of Social Inequality. New York: Plenum, 15-86.

1997 The Pithouses of Keatley Creek. Fort Worth: Harcourt Brace College Publishers.

Hayden, Brian, editor

2000a The Ancient Past of Keatley Creek, Vol. 1: Taphonomy. Burnaby: Simon Fraser University Archaeology Press.

2000b The Ancient Past of Keatley Creek, Vol. 2: Socioeconomy. Burnaby: Simon Fraser University Archaeology Press.

2004 The Ancient Past of Keatley Creek, Vol. 3: Excavations and Artifacts. Burnaby: Simon Fraser University Archaeology Press.

Hoffman, Brian

1999 "Agayadan Village: Household Archaeology on Unimak Island, Alaska," Journal of Field Archaeology 26: 147-161.

Ingold, Tim

1983 "The Significance of Storage in Hunting Societies," Man (NS) 18: 553-571.

1987 The Appropriation of Nature. Iowa City: University of Iowa Press.

Jermann, Jerry V., David V. Lewarch, and Sarah Campbell

1975 Salvage Excavations at the Kersting Site (45-CL-21): A Preliminary Report. Seattle: Office of Public Archaeology, Institute for Environmental Studies, University of Washington.

Kaehler, Gretchen Ann

2002 "Patterns in Glass: The Interpretation of European Glass Trade Beads from Two Protohistoric Sites in the Greater Lower Columbia River Region," unpublished M.A. thesis, Portland State University.

Kelly, Robert L.

1995 The Foraging Spectrum: Diversity in Hunter-Gatherer Lifeways. Washington D.C.: Smithsonian Institution Press.

Kent, Susan

1999 "The Archaeological Visibility of Storage: Delineating Storage from Trash Areas," American Antiquity 64: 79-94.

Losey, Robert J.

2002 "Communities and Catastrophes: Tillamook Response to the A.D. 1700 Earthquake and Tsunami, Northern Oregon Coast," unpublished Ph.D. dissertation, University of Oregon.

Lyman, R. Lee, and Kenneth M. Ames

2005 "Sampling to Redundancy in Zoorchaeology: Lessons from the Portland Basin, Northwestern Oregon and Southwestern Washington," Journal of Ethnobiology 24 (2): 329-346.

MacDonald, George F.

1984 "The Epic of Nekt: The Archaeology of Metaphor," in Margaret Seguin, ed., The Tsimshian: Images of the Past, Views of the Present. Vancouver: University of British Columbia Press, 65-81.

1989 Kitwanga Fort Report. Quebec: Canadian Museum of Civilization.
Matson, R. G.

1985 "The Relationship between Sedentism and Status Inequalities Among Hunter-Gatherers," in Marc Thompson, Maria T. Garcia, and Francoise J. Kense, eds., Status, Structure and Stratification: Current Archaeological Reconstructions. Calgary: Archaeological Association of the University of Calgary, 245-252.

Minor, Rick, Kathryn A. Toepel, and Steven D. Beckham

1989 An Overview of Investigations at 45SA11: Archaeology in the Columbia River Gorge, revised edn. Heritage Research Associates Report No. 83. Eugene: Heritage Research Associates.

Moulton, Gary E., editor

2002 The Journals of the Lewis and Clark Expedition. Lincoln: University of Nebraska Press.

O'Rourke, Leslie

2005 "The Wapato Valley Predictive Model: Prehistoric Archaeological Site Location on the Floodplain of the Columbia River in the Portland Basin," unpublished M.A. thesis, Portland State University.

Pettigrew, Richard $M$.

2005 Archaeological Excavations at the St. Johns Site (35MU44/46), Portland Oregon. Seattle: Cascadia Archaeology.

Price, T. Douglas, and James A. Brown

1985 Prehistoric Hunter-Gatherers: The Emergence of Cultural Complexity. Orlando: Academic Press, Inc.

Saleeby, Rebecca

1983 "Prehistoric Settlement Patterns in the Portland Basin on the Lower Columbia River: Ethnohistoric, Archaeological and Biogeographic Perspectives," unpublished Ph.D. dissertation, University of Oregon.

Samford, Patricia

1996 "The Archaeology of African-American Slavery and Material Culture," William and Mary Quarterly 53: 87-114.

Silverstein, Michael

1990 "Chinookans of the Lower Columbia" in Wayne Suttles, ed., Handbook of North American Indians, Vol. 7, The Northwest Coast. Washington, D.C.: Smithsonian Institution, 533-546.

Smith, Bruce D.

2001 "Low-Level Food Production," Joumal of Archaeological Research $9(1): 1-43$.

Smith, Cameron M.

2004 "The Social Organization of Production in Three Protohistoric Lower Columbia River Plank Houses," unpublished Ph.D. dissertation, Simon Fraser University, Burnaby, B.C.

2006 "Formation Processes of a Chinookan Plankhouse", in Elizabeth A. Sobel, D. Anne Trieu Gahr, and Kenneth M. Ames, eds., Household Archaeology on the Northwest Coast. Archaeological Series 16. Ann Arbor: International Monographs in Archaeology, 233-269.

2008 The Social Organization of Production in Three Protohistoric Lower-Columbia River Plankhouses. B.A.R International Series 1741. Oxford: Archaeopress.

Sobel, Elizabeth A.

2004 "Social Complexity and Corporate Households on the Southern Northwest Coast, A.D. 1400-1840," unpublished Ph.D. dissertation, University of Michigan. 
Sobel, Elizabeth A., D. Ann Trieu Gahr, and Kenneth M. Ames, editors

2006 Household Archaeology on the Northwest Coast. Ann Arbor: International Monographs in Archaeology.

Soffer, Olga

1989 "Storage, Sedentism, and the Eurasian Palaeolithic Record," Antiquity 64: 719-732.

Steele, Harvey

1980 Bachelor Island. Report No. 8. Portland: Oregon Archaeological Society.

Strasser, Thomas F.

1997 "Storage and State on Prehistoric Crete: The Function of the Koulouras in the First Minoan Palaces," Jourmal of Mediterranean Archaeology 10: 73-100.

Stuiver, M., and P. J. Reimer

1993 "Extended 14C Database and Revised CALIB Radiocarbon Calibration Program," Radiocarbon 35: 215-230.

Suttles, Wayne

1990 "Introduction," in Wayne Suttles, ed., Handbook of North American Indians, Vol. 7, The Northwest Coast. Washington D.C.: The Smithsonian Institution, 1-15.

Testart, Alain

1982 "The Significance of Food Storage among Hunter-Gatherers: Residence Patterns, Population Densities, and Social Inequalities," Current Anthropology 23: 523-538.

Vancouver, George

1926 The Exploration of the Columbia River by Lieutenant W. R. Broughton, October 1792: An Extract of the Journal of Captain George Vancouver. Longview, WA: Press of the Longview Daily News.

Vastokas, Joan M.

1966 Architecture of the Northwest Coast Indians. Ph.D. Dissertation, Columbia University. Ann Arbor: University Microfilms.

Wesson, Cameron B.

1999 "Chiefly Power and Food Storage in Southeastern North America," World Archaeology 31: 145-164.

Wilson, Douglas C.

1994 "Identification and Assessment of Secondary Refuse Aggregates," Journal of Archaeological Method and Theory 1: 41-68.

Wilson, Douglas C., and Robert Cromwell

2005 Management Summary: Data Recovery Excavations at Station Camp/McGowan Site (45 PC 106) within the Proposed Right-of-Way for US Highway 101 Realignment: Pacific County Washington. Vancouver National Historic Reserve: National Park Service.

Wolf, John

1994 "The Spatial Distribution of Ground Stone Tools As a Marker of Status Differentials in a Chinookan Plank House on the Lower Columbia River," unpublished M.A. thesis, Portland State University, Portland.

Young, Amy Lambeck

1995 Risk and Material Conditions of African American Slaves at Locust Grove: An Archaeological Perspective. Nashville: University of Tennessee.

Zenk, Henry B.

1976 "Contributions to Tualatin Ethnography: Subsistence and Ethnobiology," unpublished M.A. thesis, Portland State University. 